KRZYSZTOF NOWOSIELSKI

\title{
Controlling process performance indicators. Results of empirical and theoretical research
}

"If you can't measure something, you can't understand it. If you can't understand it, you can't control it. If you can't control it, you can't improve it."

H. James Harrington (1987, s. 43)

\section{Introduction}

Controlling, as management concept widely employed among European enterprises is oriented towards increasing the level of business goals achievement. The role of a controller in a company is to unburden managers by taking over specific tasks (e.g. organizing planning activities or providing information) and prevent managers from making inefficient decisions, striving to assure the rationality of corporate management (ICV-IGC 2013, p.313). An efficient controller contributes to the achievement of business goals. Therefore, it is clear that, by making an assessment of economic performance of a given company an indirect assessment of the controlling processes is being made. However, despite the fact that every modern enterprise has a very well developed performance measurement system, it is very rare for this system to encompass results of controlling

Ph.D. Krzysztof Nowosielski Wrocław University of Economics processes as well. Observations of both, controlling experts and the author of this article confirm these findings. As indicated by, e.g. 
U. Schäffer, J. Weber and E. Strauß (2012, p.12), the key area of controller's interest is the efficiency of his company, nevertheless, the efficiency of controlling itself is rarely taken into consideration. Similarly, H. Losbichler $(2012$, p. 2$)$ argues that in today's challenging economic environment, companies increasingly question the efficiency and effectiveness of their controlling activities and that controllers measure everything but their own performance. In the literature, propositions of controlling performance indicators can be found, although they are discussed mainly from a theoretical standpoint (Hoffjan, Kolburg, Ufer 2010, p.96). In order for the controlling processes to be managed and improved successfully, it is important to implement specific indicators and not relying solely on general perception while assessing these processes. As S. Tonchia and L. Quagini (2010, p.3) state, experience, intuition, and in certain cases luck, are really important, but within the scope of a scientific-based management the presence of adequate methods and measuring instruments are by far the most important aspect. A systematic measurement and assessment of controlling processes ought to enable establishing their current condition and planning further development actions.

The aim of this article is to introduce the performance indicators that can be used in assessment of controlling processes in an enterprise. For the purpose of this, a literature review as well as an analysis of empirical research results carried out by the author between years 2012-2013 among companies operating in Poland were performed. The research was conducted via surveys and concerned the measures used in the assessment of controlling as well as their employment in the process of controlling improvement.

The article is constructed in the following manner: an introduction, three main sections and a summary. The first section deals with the idea of controlling processes as well as their relation to the management processes. Next, the latest indicator concepts proposed by controlling experts are presented. The latter section describes the results of empirical research and the conclusion that comes from it as well as indicates issues that require further scientific discussion.

\section{The idea of process approach to controlling concept}

The process approach to controlling is not a commonly encountered idea. The literature consists predominantly of studies describing the functions, organisation and instrumentation of controlling. Scarce studies devoted to the aspect of process approach to controlling were, in most cases, created by the business experts involved in controlling issues (cf. IGC 2012a; DIN SPEC 1086). 
As claimed by C.A. Rummler and A.P. Brache (2000, p.95), it is the processes where the greatest possibilities for the improvement of management system. It is mainly due to the fact that such an approach enables an understanding of company's functioning.

In the following article a "process" is defined as a "set of interrelated or interacting activities, which transforms inputs into outputs". These activities require allocation of resources such as people and materials (for further details see ISO/TC 176/SC 2/N 544R3). Following the foregoing definition, controlling has been defined as a business process, which main objective is to support management of a company. Figure 1 depicts the idea of a process approach to the issue of controlling.

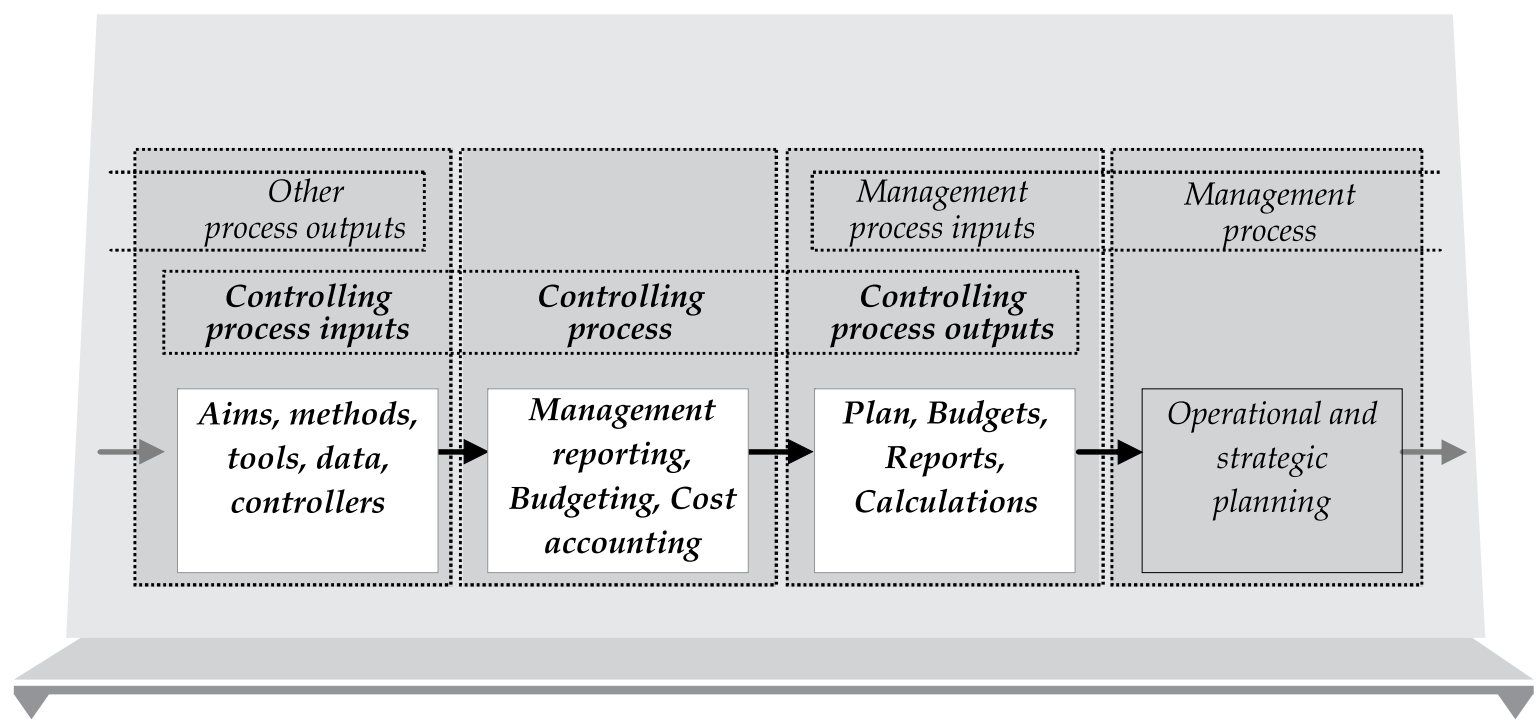

Figure 1. The idea of process approach to the issue of controlling

Source: own materials

According to the International Group of Controllers, IGC, the main process of controlling comprises, among other things, with such specific processes as: operational planning and budgeting, management reporting, cost accounting or forecasting (cf. the definition and exemplary controlling processes Nowosielski: 2011, pp.245-248). A controller is fully or partially responsible for these processes (it depends on controllers tasks in individual company). His main task is to support the manager (controller service function) in decisions making process. The responsibility for results of these decisions, however, lies with the manager.

Controlling process performance indicators. Results of empirical and theoretical research 
The controller, on the other hand (Deyhle 2003, p.53; DIN SPEC 1086, p.5):

- makes sure that the management processes are transparent and reliable,

- coordinates individual plans and goals as well as organises goal-oriented reporting system,

- moderates goal establishing processes as well as planning and control processes ensuring that every decision-maker can operate properly,

- provides services of giving access to business information and data,

- cares about the development of the controlling system

Processes of controlling, such as management reporting process, require specific input resources, such as: aims, methods, tools, data (information) and human resources. The results of controlling processes (products e.g. management reports, budgets) constitute further input of management processes. Implementing appropriate measures, especially covering the outputs (results, products) of controlling processes, should provide valuable information that can be used to improve these outputs and processes as well. This, in turn, should improve internal customers' satisfaction, the quality of the economic decisions and the economic performance of the business unit.

\section{Performance measurement of controlling processes. State-of-the-art}

The performance measurement can be defined as the process of quantifying the efficiency and effectiveness of action and performance measurement system as the set of metrics used to quantify both the efficiency and effectiveness of actions (Neely, Gregory, Platts 1995, p.80). Such an approach to the performance measurement system enables a broad construction of a set of indicators, including various types of measures ${ }^{1^{*}}$ (both, financial and non-financial, process and process results oriented) adjusted to the specific needs of decision-makers and the character of assessed objects. Obtaining knowledge on the given object through the prism of assumed criteria should be the benefit of incorporating the measurement. This knowledge should enable such conduct of an entity which leads its state to the desired level (target value) in the future.

In the literature, more and more attention is given to the issues of performance measurement of controlling. Already back in the 1980's, K.D. Fressman (1980, p.150) noticed the need for performance measurement of controlling seen

$1 \mathrm{n}$ this article words measure and indicator are used interchangeably despite of the specific differences between them (cf. IGC 2012b) 
through the prism of the level of successful deadline meeting and controlling customer's satisfaction of their processes and products. A. Brokeamper (2000) took a similar notice, additionally focusing on the need for measurement of controlling costs. J.Weber (2011, pp.28-30), on the other hand, qualifies the manner and the direction of controller's tasks development in a company in terms of the results of controlling effectiveness and efficiency measurement. By studying the internal orientation of the controlling processes, D.Spillecke (2006, pp. 118-404) proposes, among other things, measurements of:

- the quality of controlling process outputs (results), from the perspective of controlling customers,

- the adequacy and punctuality of information delivery by the controllers,

- general managers' (internal customers) satisfaction with the controlling results.

Similar proposals were put forward by J. Künkele i U. Schäffer (2007, pp.75-92), who postulate performing the measurement of the level to which controllers support the budgeting process. They stress the relevance of the information provided in terms of what the managers need and what is up-to-date and the quality of the services provided by controllers, for example presentation of financial data. In another proposition, M. Eckey and U. Schäffer (2006, pp.251280) focus on the need to measure the reliability and the level to which the data provided by the controllers represents the actual state of affairs.

At this point, it is worth to mention a document created by experts from the International Group of Controllers (IGC), who developed a set of key performance indicators for controlling processes (IGC 2012b). It is the first, consistent study containing a coherent list of such indicators. The authors proposed a number of measures for every identified controlling process grouped in three complementary perspectives: quality, time and cost. Table 1 depicts chosen indicators (with algorithms) comprised by IGC. In above mentioned list of measures, the basic indicators were described at the level of individual controlling processes. The authors see the possibility to identify and implement a more detailed indicators as e.g. for the sub-processes and inputs (resources) or outputs (results) of a given process. These indicators can be created at various levels of information aggregation. Every controlling process was fitted with a number of suited indicators for every assessment perspective (quality, time, cost). It was also described in details. For instance, the authors propose the punctuality of management report delivery as one of the indicators of the management reporting process. A more detailed description of this indicator looks as follows (IGC 2012b, pp.62-63): 
- the objective of related process: punctual information,

- the name of the indicator: punctuality understood as delivering reports on time,

- the calculation algorithm: standards reports presented on agreed date (number) / total standards reports (number) * 100,

- significance: the extent to which the indicator influences the reliability of reporting schedule,

- an exemplary result interpretation: e.g. a possible shortage of resources,

- frequency of measuring the indicator: monthly.

Table 1. Sample indicators for controlling processes according to IGC brochure

\begin{tabular}{|c|c|c|c|}
\hline \multirow{2}{*}{$\begin{array}{c}\text { Controlling } \\
\text { process }\end{array}$} & \multicolumn{3}{|c|}{ Perspective } \\
\hline & Quality & Time & Cost \\
\hline $\begin{array}{l}\text { Operational } \\
\text { and budget } \\
\text { planning }\end{array}$ & $\begin{array}{c}\text {-Budget variance } \\
\text { [(EBIT actual - EBIT } \\
\text { budget }) / E B I T \text { bud- } \\
\text { get*100] } \\
\text {-Customer satisfac- } \\
\text { tion } \\
\text { [survey] }\end{array}$ & $\begin{array}{l}\text {-Lead time } \\
\text { [working days from start (plan- } \\
\text { ning briefing) to finish (board } \\
\text { approval)] } \\
\text {-Planning loops } \\
\text { [number] }\end{array}$ & $\begin{array}{c}\text {-FTE } \\
\text { [full-time equivalent] } \\
\text {-Process costs } \\
\text { [personal costs + share in } \\
\text { costs of materials] } \\
\text {-Process costs }(\text { sales) } \\
\left.\text { [Process costs / sales }{ }^{*} 100\right]\end{array}$ \\
\hline $\begin{array}{l}\text { Management } \\
\text { reporting }\end{array}$ & $\begin{array}{c}\text {-Report length } \\
\text { [number of pages of the } \\
\text { standard report] } \\
\text {-Errors in the report } \\
\text { [number] } \\
\text {-Customer satisfac- } \\
\text { tion } \\
\text { [survey] }\end{array}$ & $\begin{array}{c}\text {-Lead time } \\
\text { [working days required to pre- } \\
\text { pare the report] } \\
\text {-Punctuality } \\
\text { [standards reports presented } \\
\text { on agreed date (number) / total } \\
\text { standards reports (number) * } \\
\text { 100] }\end{array}$ & $\begin{array}{c}\text {-FTE } \\
\text { [full-time equivalent] } \\
\text {-Process costs } \\
\text { [personal costs }+ \text { share in } \\
\text { costs of materials] } \\
\text {-Process costs }(\text { sales) } \\
\left.\text { [Process costs / sales }{ }^{*} 100\right]\end{array}$ \\
\hline $\begin{array}{l}\text { Cost } \\
\text { accounting }\end{array}$ & $\begin{array}{l}\text {-Share of controllable } \\
\text { costs } \\
\text { [controllable costs / total } \\
\left.\text { costs }{ }^{*} 100\right] \\
\text {-Customer satisfac- } \\
\text { tion } \\
\text { [survey] }\end{array}$ & $\begin{array}{c}\text {-Lead time } \\
\text { [working days from start (re- } \\
\text { quest) to finish (presentation cost } \\
\text { accounting report)] } \\
\text {-Response time } \\
\text { [working days from start (re- } \\
\text { quest) to finish (presentation } \\
\text { calculation)] }\end{array}$ & $\begin{array}{c}\text {-FTE } \\
\text { [full-time equivalent] } \\
\text {-Process costs } \\
\text { [personal costs }+ \text { share in } \\
\text { costs of materials] } \\
\text {-Process costs }(\text { sales) } \\
\left.\text { [Process costs / sales }{ }^{*} 100\right]\end{array}$ \\
\hline
\end{tabular}

Source: own study based on IGC 2012b, pp.56-63 
The diversity of the proposed controlling assessment indicators opens a wide range of possibilities for its assessment and improvement. The authors of the model rightfully indicate, however, that the each measure are to be adapted to the unique company as well as the requirements of the recipients of assessment results.

\section{Empirical research results}

The empirical research conducted by the author between years 2012-2013 was aimed at recognizing the measures used in the assessment of controlling and the ways of its improvement in enterprises. The business units invited to the study where those, that implemented or were in the process of implementing controlling. In the result 82 entries came in, 67 of which were included in the analysis. The questionnaire entries not included in the further stages of the research came from the units that did not provide answers to the questions concerned with the assessment of controlling, employment of the controlling manuals and organisational form of controlling. This exclusion does not influence presented conclusions. Due to a low number of records collected in the research the results presented below should be treated solely in terms of their informational value and should not be used for the basis of generalisation of findings.

The surveyed units represented a variety of business sectors, company sizes and had various level. Large companies with a yearly turnover exceeding $100 \mathrm{~m}$ PLN and hiring more than 250 employees constituted about $40 \%$ of the all companies. Close to $50 \%$ of them declared having used controlling for a period of 5 years or more, and 35\% for a period of over 10 years.

On the basis of the gathered data the answers to the following questions were sought:

- Do companies assess the results of controlling processes?

- What measures are used in the assessment of controlling process outputs?

- Has any type of formalised procedure for controlling assessment been implemented?

- What are the results of the assessment used for?

The questions used in the questionnaire were based on management reports, as sample controlling process results. For such an object of research, a set of key indicators had been prepared for the three assessment perspectives comparable to the IGC experts' proposition (cf. IGC 2012b, p. 62). Six indicators grouped into three groups were indicated:

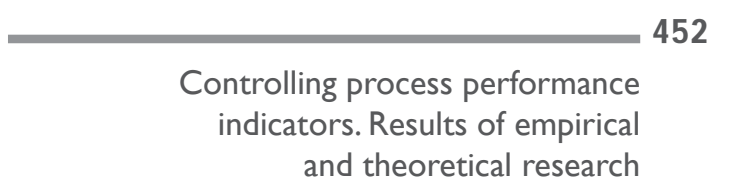


- Quality - including the completeness, reliability and usefulness of report,

- Time - including punctuality in report delivering and lead time (time required to prepare report),

- Costs - Costs of report preparation .

To every question concerning the measures of controlling processes, the respondents could choose one of four possible answers:

- no such measurement and assessment is conducted,

- the assessment based on pointed measure is conducted, but in informal way (measurement has not been specified in companies' documentation and relies heavily on perception measures),

- the assessment based on pointed measure is conducted in a formal way (it is specified in companies' documentation and it is based on specific indicators),

- no answer (records excluded from analysis).

The data gathered in research process indicate that the concept of controlling results measurement and assessment (in the case of this study - controlling reports) is not completely unfamiliar to the respondents (see figure 2). However only few companies declared conducting an assessment in a formalised manner using specific indicators.

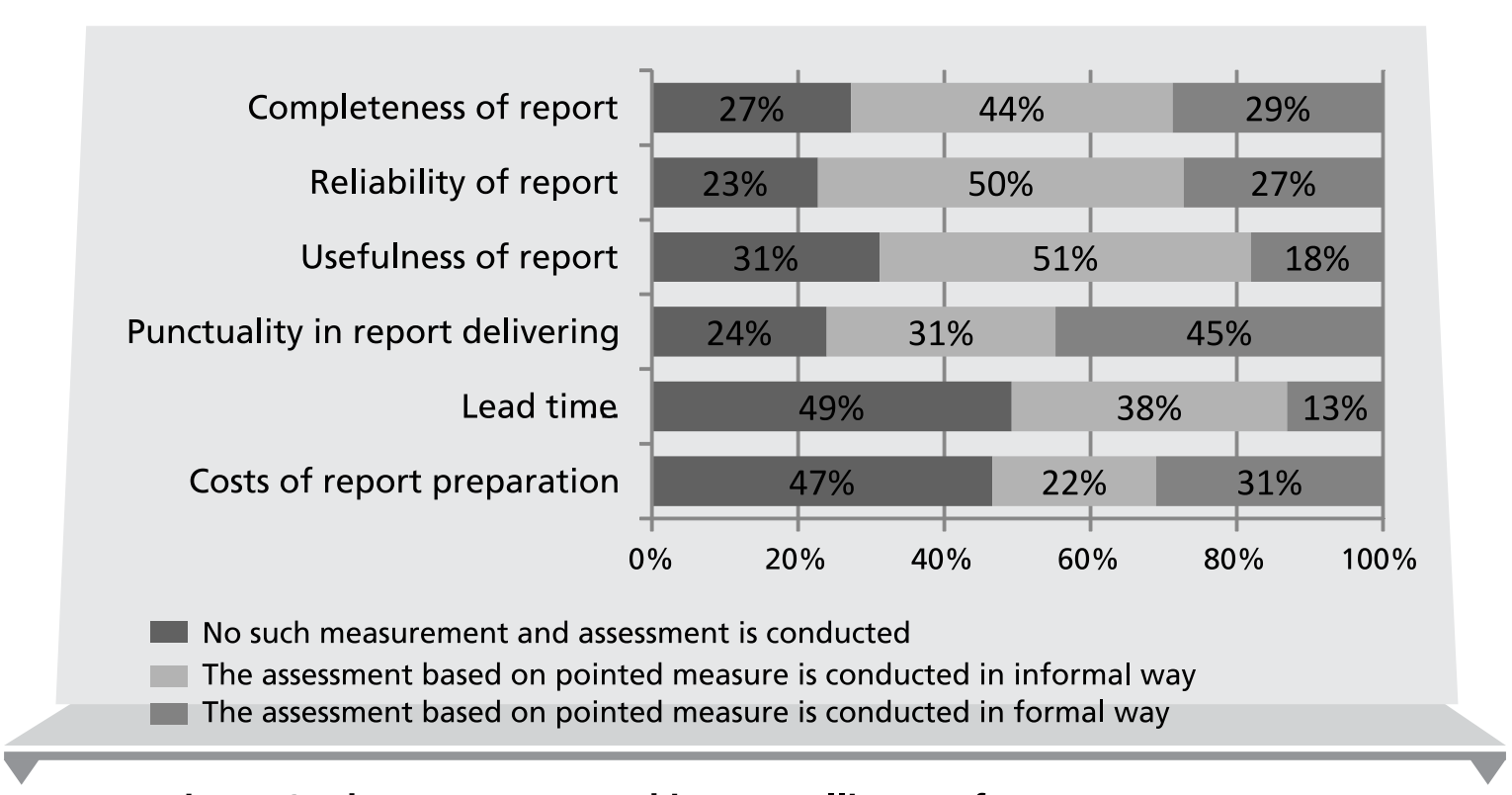

Figure 2. The measures used in controlling performance assessment in the surveyed companies

Source: own materials 
Over $70 \%$ of the respondents declared conducting assessment of the quality of reports (in terms of their completeness, reliability and usefulness). Although, only $20 \%$ admitted they conduct such an assessment in a formalised manner. This indicates that in the case of the remaining $50 \%$ of units the quality assessment is based on subjective perception and not clearly specified measures. In the case of indicators concerning time measures (punctuality in report delivering and time required to prepare reports) one can see a whole variety of answers. Analysing these measures separately the difference between the answers can be noticed. In terms of punctuality nearly a half $(45 \%)$ of the units declared conducting the assessment of this parameter in a formalised way. In the surveyed companies, it was the most commonly employed indicator of controlling assessment (regardless of the size of companies and the "age" of controlling). What is interesting, only one in nine companies was using the measure of lead time (time required to prepare reports) in their controlling process assessment. As for the costs of report preparing, $50 \%$ of the respondents declared assessment of this indicator, one in three of which did it in a formalised manner. Over $60 \%$ of the units used the results of controlling assessment in the process of controlling improvement, and $35 \%$ used it to reward controllers.

In order to get a more detailed picture of the collected data, two additional calculations (table 2 and table 3 ) have been prepared (the number of researched units (n) in an individual measures may differ, what is connected with respondents, who gave no answer to the question).

In the former table, the surveyed companies have been divided into those which had and had not implemented controlling manuals (criterion - formalisation of controlling). The latter represents the results for the units where controlling has an institutional form (a separate controlling department or position) as well as the units that implemented, so called, non-institutional controlling, where controllers tasks are assigned to various departments or positions (criterion institutionalisation of controlling).

In total, $42 \%$ of respondents declared employing controlling manuals, the rest did not have any such document or were in the process of its creation. In the group of companies, where controlling were documented in form of manual it is clearly visible, that in comparison to the overall results (Figure 2) there are much more units using specific measures in controlling process assessment. Such correlation can be found with every indicators. On the other hand, among the companies that had not introduced such manual an informal assessment was the dominant mode of operation. Most probably, it was conducted on the basis of an unstandardized observation of controlling processes and results. 
Table 2. Measures of controlling in the surveyed companies in terms of controlling formalisation

\begin{tabular}{|c|c|c|c|c|c|c|}
\hline \multirow{2}{*}{ ن } & \multirow[b]{2}{*}{ Indicators } & \multirow{2}{*}{$\begin{array}{l}\text { Is control- } \\
\text { ling manual } \\
\text { developed? }\end{array}$} & \multicolumn{3}{|c|}{ Manner of assessment } & \multirow[b]{2}{*}{ Total \% (n) } \\
\hline & & & $\begin{array}{l}\text { Assessment } \\
\text { is not per- } \\
\text { formed }\end{array}$ & $\begin{array}{l}\text { Assessment } \\
\text { is informal }\end{array}$ & $\begin{array}{c}\text { Assessment } \\
\text { is formal }\end{array}$ & \\
\hline \multirow{9}{*}{ 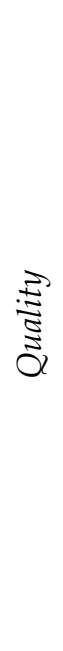 } & \multirow{3}{*}{$\begin{array}{c}\text { Report comlete- } \\
\text { ness }\end{array}$} & No & - & -ma $50 \%$ & प्मप० $18 \%$ & घ"a $100 \%(38)$ \\
\hline & & Yes & -प⿴囗十 $21 \%$ & 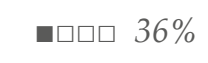 & - $43 \%$ & 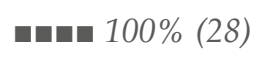 \\
\hline & & Total \% & - प्र० $27 \%$ & ㅁㅁ $44 \%$ & घम०० 29\% & שם 100\% (66) \\
\hline & \multirow{3}{*}{ Report reliability } & No & घᄆम $29 \%$ & Dᄆ⿴囗十 $58 \%$ & 맘 $13 \%$ & m 100\% (38) \\
\hline & & Yes & प्वप $14 \%$ & - प्रम 39\% & שேम $47 \%$ & and $100 \%$ (28) \\
\hline & & Total \% & - & - & घपि口 $27 \%$ & שם 100\% (66) \\
\hline & \multirow{3}{*}{ Report usefulness } & No & 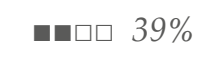 & -ma $53 \%$ & प्वप्र $08 \%$ & 100\% (36) \\
\hline & & Yes & घमिप $20 \%$ & - $48 \%$ & घᄆमप $32 \%$ & an 100\% (25) \\
\hline & & Total \% & - & - $51 \%$ & प्रिए $18 \%$ & a日a $100 \%$ (61) \\
\hline \multirow{6}{*}{$\underset{i=}{\rightleftarrows}$} & \multirow{3}{*}{$\begin{array}{l}\text { Punctuality of } \\
\text { report delivering }\end{array}$} & No & - & घᄆवप $33 \%$ & घपि口 $36 \%$ & घ"घ 100\% (39) \\
\hline & & Yes & प्र० $14 \%$ & प्वपए 29\% & घघमप 57\% & 100\% (28) \\
\hline & & Total \% & घमिए $24 \%$ & - & घघ口๐ $45 \%$ & שघ 100\% (67) \\
\hline & \multirow{3}{*}{$\begin{array}{l}\text { Lead time (time } \\
\text { required to pre- } \\
\text { pare report) }\end{array}$} & No & 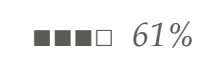 & घᄆaप $33 \%$ & प्रिप $06 \%$ & an $100 \%(36)$ \\
\hline & & Yes & - प्रम $32 \%$ & -1⿴囗十 $44 \%$ & प्रिए $24 \%$ & a日u $100 \%$ (25) \\
\hline & & Total \% & 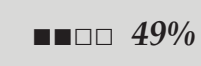 & घमप॰ 38\% & ㅁㅁ 13\% & 100\% (61) \\
\hline \multirow{3}{*}{$\overrightarrow{0}$} & \multirow{3}{*}{$\begin{array}{l}\text { Costs of report } \\
\text { preparation }\end{array}$} & No & שपम 58\% & घᄆमप $27 \%$ & प्रिप $15 \%$ & 100\% (33) \\
\hline & & Yes & घमपर $32 \%$ & ㅁㅁ $16 \%$ & घயम $52 \%$ & घ" 100\% (25) \\
\hline & & Total \% & घ"मே $47 \%$ & प्रमप $22 \%$ & घमㅁ $31 \%$ & บ 100\% (58) \\
\hline
\end{tabular}

Source: own materials

The results observed in the table 3 can be interpreted in a similar way. Among the subjects, that did not create a separate department or position of controlling in their organisational structure, there was no formal assessment 
Table 3. Measures of controlling in the surveyed companies in terms of controlling institutionalisation

\begin{tabular}{|c|c|c|c|c|c|c|}
\hline \multirow{2}{*}{$\frac{0}{\sqrt[0]{2}}$} & \multirow[b]{2}{*}{ Measure } & \multirow{2}{*}{$\begin{array}{l}\text { Has control- } \\
\text { ling institu- } \\
\text { tional form? }\end{array}$} & \multicolumn{3}{|c|}{ Manner of assessment } & \multirow[b]{2}{*}{ Total \% (n) } \\
\hline & & & $\begin{array}{c}\text { Assessment } \\
\text { is not per- } \\
\text { formed }\end{array}$ & $\begin{array}{l}\text { Assessment } \\
\text { is informal }\end{array}$ & $\begin{array}{c}\text { Assessment } \\
\text { is formal }\end{array}$ & \\
\hline \multirow{9}{*}{$\underset{\frac{\vec{a}}{5}}{\stackrel{\overrightarrow{5}}{0}}$} & \multirow{3}{*}{$\begin{array}{l}\text { Report comle- } \\
\text { teness }\end{array}$} & No & - & 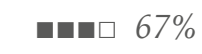 & प्रिए 00\% & m $100 \%(06)$ \\
\hline & & Yes & - $27 \%$ & घaपि $41 \%$ & - प्र० $32 \%$ & and $100 \%$ (60) \\
\hline & & Total \% & - $27 \%$ & - & घमिए $29 \%$ & an日 100\% (66) \\
\hline & \multirow{3}{*}{$\begin{array}{l}\text { Report relia- } \\
\text { bility }\end{array}$} & No & प्रमप $17 \%$ & m $83 \%$ & प्रिम $00 \%$ & an=100\% (06) \\
\hline & & Yes & - $23 \%$ & ma $47 \%$ & - & ตח 100\% (60) \\
\hline & & Total $\%$ & - $23 \%$ & - $50 \%$ & घमिप $27 \%$ & 100\% (66) \\
\hline & \multirow{3}{*}{$\begin{array}{c}\text { Report useful- } \\
\text { ness }\end{array}$} & No & - & $\operatorname{man} 67 \%$ & प्रिम $00 \%$ & an=100\%(06) \\
\hline & & Yes & - & - 490 & घutu $20 \%$ & בח 100\% (55) \\
\hline & & Total \% & घपि口 $31 \%$ & - & प्रमप $18 \%$ & -100\% (61) \\
\hline \multirow{6}{*}{ 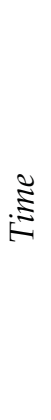 } & \multirow{3}{*}{$\begin{array}{c}\text { Punctuality of } \\
\text { report deliver- } \\
\text { ing }\end{array}$} & No & $83 \%$ & प्र०० $00 \%$ & पमपर $17 \%$ & an 100\%(06) \\
\hline & & Yes & प्रमप $18 \%$ & - $34 \%$ & 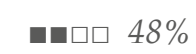 & घ"100\% (61) \\
\hline & & Total \% & घपि口 $24 \%$ & - प्रि $31 \%$ & 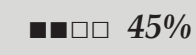 & שח 100\% (67) \\
\hline & \multirow{3}{*}{$\begin{array}{c}\text { Time required } \\
\text { to prepare } \\
\text { report }\end{array}$} & No & घma $67 \%$ & घaप्र $33 \%$ & प्रिप $00 \%$ & घum 100\% (06) \\
\hline & & Yes & - $47 \%$ & - घम० $38 \%$ & प्मिए $15 \%$ & m $100 \%(55)$ \\
\hline & & Total $\%$ & 4ח $49 \%$ & - $38 \%$ & प्रिए $13 \%$ & בשם 100\% (61) \\
\hline \multirow{3}{*}{$\overrightarrow{\tilde{d}}$} & \multirow{3}{*}{$\begin{array}{c}\text { Costs of report } \\
\text { preparation }\end{array}$} & No & - $80 \%$ & - प्र० $20 \%$ & प्रिम $00 \%$ & an=100\% (05) \\
\hline & & Yes & -mb $43 \%$ & - & -प्रि $34 \%$ & and 100\% (53) \\
\hline & & Total \% & - $47 \%$ & - $22 \%$ & 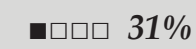 & 100\% (58) \\
\hline
\end{tabular}

Source: own materials

at all, no specific measures were used. It is clearly visible that, in the case of the indicators concerning punctuality of report delivering, the time and 
costs connected with their preparation, most of the surveyed companies did not conduct such an assessment. These results, however, cannot be deemed authoritative as, compared to the total number of surveyed units, the companies where controlling took a non-institutional form constituted merely $10 \%$ of all units. Similarly, as in the case of the former table, in the group of subjects where controlling has an institutional form it can be noticed that, in comparison to the overall results (figure 2), there are more units using specific measures in controlling process assessment.

\section{Summary}

Controlling is an important element of management system in every modern enterprise. By definition, it is to bring positive effects in form of a high level of business long- and short-term goals achievement. The knowledge whether this is true or not should constitute an important factor in making decisions concerning the development of controlling in a company. The article brings to light the manner in which this knowledge is obtained stressing the measurable indicators of controlling performance. Information obtained through conducting an assessment of controlling processes and their results should be considered essential, for it is impossible to make proper decisions shaping controlling without paying attention to costs and benefits it provides. It is also impossible to assume a priori the effectiveness and efficiency of such a management concept. Literature analysis provides evidence that controlling experts are familiar with the issues discussed in this article. Similarly, controlling experts understand the problematic nature of controlling implementation and functioning, which is additionally proven by the empirical research results conducted by the author.

In the article only fragmented part of the research results were conducted. Further, intense research in the area of controlling process performance should be provided. It is important to research how to measure and asses controlling processes, as well as ways of utilising the assessment results in the improvement of these processes. The vast body of literature devoted to this subject, especially that in German-speaking countries, can indicate high significance of these issues.

\section{Summary}

Key performance indicators for controlling processes. Results of empirical and theoretical research

The article sheds light on the issue of controlling performance 
measurement on the basis of the available literature and empirical research conducted by the author. Sample indicators have been provided, which can be used to confirm the efficiency of using controlling in a company as well as to determine the steps of its improvement and development.

Keywords: controlling process, measurement, efficiency, effectiveness, performance indicators.

\section{Streszczenie}

Wskaźniki dokonań controllingu. Ujęcie teoretyczne oraz wyniki badań empirycznych

W artykule przybliżono zagadnienie pomiaru dokonań controllingu opierając się na dorobku literaturowym oraz badaniach empirycznych prowadzonych przez autora. Wskazano miary, które mogą być wykorzystane $\mathrm{w}$ pomiarze i ocenie procesów controllingu i ich rezultatów. Wyniki pomiaru mogą być wykorzystywane w celu potwierdzenia sprawności stosowania controllingu $\mathrm{w}$ przedsiębiorstwie oraz określenia ścieżek jego doskonalenia i rozwoju.

\section{Słowa}

kluczowe: procesy controllingu, pomiar, efektywność, skuteczność, wskaźniki dokonań.

\section{References}

1. Brokeamper A. (2000), Wir sind doch alle kundenorientiert? Sieben Schritte zum kunden- und marktorientierten Controlling, strona internetowa: http:/ / www.controller-forum.com/2000/docs/brokemper.pdf (12.07.2003 data dostępu).

2. Deyhle A. (2003), Was ein Controller so alles konnen muss ..., "Controlling \& Management", No. 47.

3. DIN SPEC 1086:2009-04 (2009) Quality standards for controlling.

4. Eckey M., Schäffer U. (2006), Kontrolle von Mehrheitsbeteiligungen in börsennotierten Management-Holdings, "Zeitschrift für Planung \& Unternehmenssteuerung", Vol. 17.

5. Fessmann K.D. (1980), Organizatorische effizienz in Unternehmungen und Unternehmung-Teilbereihen, Mannhold, Dusseldorf.

6. Flapper S.D.P., Fortuin L., Stoop P.P.M. (1996), Towards consistent perfor- 
mance management systems, "International Journal of Operations \& Production Management", Vol. 16, No. 7.

7. Harrington H.J. (1987), The improvement process: how America's leading companies improve quality, McGraw-Hill, New York.

8. Hoffjan A., Kolburg A., Ufer W. (2010), Controllingeffizienz in der Praxis Effizienzverständnis, Einflussfaktoren, Maßnahmen, "Controlling \& Management", No. 54.

9. ICV-IGC(2013), The essence of Controlling - theperspective of the Internationaler Controller Verein (ICV) and the Internatinal Group of Controlling (IGC)., "Journal of Management Control", No 23.

10. IGC (2012a), Controlling Process Model. A guideline for describing and designing Controlling processes, Haufe.

11. IGC (2012b), Controlling Process KPIs. A guideline for measuring performance in Controlling processes, Haufe.

12. ISO/TC 176/SC 2/N 544R3 (2008) ISO 9000 Introduction and Support Package: Guidance on the Concept and Use of the Process Approach for management systems.

13. Künkele J., Schäffer, U. (2007), Zur erfolgreichen Gestaltung der Budgetkontrolle, "Die Betriebswirtschaft", Vol. 67.

14. Losbichler H. (2012), Measuring the performance of controllers and controlling processes, "Controller Magazin", Iss. 9.

15. Neely A., Gregory M., Platts K. (1995) Performance measurement system design. A literature review and research agenda, "International Journal of Operations \& Production Management", Vol. 15, No. 4.

16. Nowosielski K. (2011), Kierunki usprawniania procesów controllingu. w: S. Nowosielski (red.), Podejście procesowe w organizacjach, Prace Naukowe Wydawnictwa Uniwersytetu Ekonomicznego we Wrocławiu, nr 169, Wrocław.

17. Rummler G.A., Brache A.P. (2000), Podnoszenie efektywności organizacji, PWE, Warszawa.

18. Schäffer U., Weber J., Strauß E. (2012), Controlling und Effizienz - Auch ein Controller muss sich rechnen!, "Controlling \& Management", Sonderheft 3.

19. Schäffer U., Steiners, D. (2004), Zur Nutzung von Controllinginformationen, "Zeitschrift für Planung und Unternehmenssteuerung", Vol. 15.

20. Spillecke D. (2006), Interne Kundenorientierung des Controllerbereichs. Messung - Erfolgsauswirkungen - Determinanten, Deutscher Universitäts Verlag, Wiesbaden.

21. Tonchia S., Quagini L. (2010), Performance Measurement. Linking Balanced Scorecard to Business Intelligence, Springer, Heidelberg, Berlin.

22. Weber J. (2011) The development of controller tasks: explaining the nature of controllership and its changes, "Journal of Management Control", No. 22. 